\title{
TINJAUAN TEORITIS EFEKTIVITAS PEMERIKSAAN PAJAK DI INDONESIA
}

\author{
Setiadi Alim Lim \\ Program Studi Akuntansi Politeknik Ubaya \\ Jalan Ngagel Jaya Selatan 169, Surabaya \\ setiadi.alim@gmail.com \\ Lilik Indrawati \\ Program Studi Manajemen \\ Fakultas Ekonomi Universitas Katolik Darma Cendika \\ Jalan Dr. Ir. H. Soekarno 201, Surabaya \\ lilik.indrawati.2013@gmail.com
}

\begin{abstract}
Each country can use a tax collection system that varies between countries. Basically, each country can choose one of the tax collection systems, namely between the official assessment system or the self assessment system. On the official assessment system the amount of tax payable and must be paid by the taxpayer is determined by the tax authority. Whereas in the self assessment system the amount of tax payable and must be paid will be calculated, deposited and reported by the taxpayer himself. Most countries in the world use the self assessment system. A country that applies the self assessment system will usually experience problems related to the low level of tax compliance. To increase the level of taxpayer compliance, countries that implement the self assessment system must routinely carry out tax audit actions to test the compliance of taxpayers. In order for the purpose of the tax audit to be achieved, the tax audit must be carried out effectively. Indicators that are usually used to assess the effectiveness of tax audits are compliance from taxpayers. The effectiveness of tax audits is also influenced by several factors that can generally be summarized into 7, namely: organization, organizational independence, taxpayer, tax audit quality, tax auditor, regulation, and management support. This research is intended to see whether the tax audit in Indonesia has been running effectively. The effectiveness of tax audits is evaluated by looking at whether the factors that influence the effectiveness of the tax audit have been included in the tax audit in Indonesia. This research is a library research with a statute approach, conceptual approach, and comparative approach. The results of the study show that from the evaluation of all factors that might influence the effectiveness of tax audits, organizational factors, tax auditors, regulations, and management support from the Directorate General of Taxation have met the criteria for the realization of effective tax audits in Indonesia. But the taxpayer factor, the independence of the organization and the tax audit quality have not supported the realization of an effective tax audit. Then when viewed from the level of taxpayer compliance as an indicator that
\end{abstract}


shows that tax audits have been carried out effectively, tax audits in Indonesia have not been effective, because the level of compliance from taxpayers is only at $62.96 \%$ for corporate taxpayers and non-individual taxpayers employees and Compliance Ratio Submission of Annual Income Tax Returns in 2017 only reached $72.64 \%$.

Keywords: official assessment system, self assessment system, tax compliance, tax audit.

\begin{abstract}
ABSTRAK
Setiap negara dapat menggunakan sistem pemungutan pajak yang berbeda-beda antar satu negara dengan negara lainnya. Pada dasarnya setiap negara dapat memilih salah satu dari sistem pemungutan pajak, yaitu antara official assessment system atau self assessment system. Pada official assessment system besarnya pajak yang terutang dan harus dibayar oleh wajib pajak ditentukan oleh otoritas pajak. Sedangkan pada self assessment system besarnya jumlah pajak yang terutang dan harus dibayar akan dihitung, disetorkan dan dilaporkan oleh wajib pajak sendiri. Sebagian besar negara-negara di dunia menggunakan self assessment system. Suatu negara yang menerapkan self assessment system biasanya akan mengalami masalah terkait dengan rendahnya tingkat kepatuhan wajib pajak. Untuk meningkatkan tingkat kepatuhan wajib pajak, negara yang menerapkan self assessment system harus secara rutin melakukan tindakan pemeriksaan pajak guna menguji kepatuhan dari wajib pajak. Agar tujuan dari pemeriksaan pajak dapat tercapai, maka pemeriksaan pajak harus dapat dilakukan secara efektif. Indikator yang biasanya dipakai untuk menilai efektivitas pemeriksaan pajak adalah kepatuhan dari wajib pajak. Efektivitas pemeriksaan pajak juga dipengaruhi beberapa faktor yang secara umum dapat diikhtisarkan menjadi 7, yaitu: organisasi, independensi organisasi, wajib pajak, kualitas pemeriksaan, pemeriksa pajak, peraturan, dan dukungan manajemen. Penelitian ini dimaksudkan untuk melihat apakah pemeriksaan pajak di Indonesia sudah berjalan secara efektif. Efektivitas pemeriksaan pajak dievaluasi dengan melihat apakah faktor-faktor yang mempengaruhi efektivitas pemeriksaan pajak telah ada di dalam pemeriksaan pajak di Indonesia. Penelitian ini merupakan penelitian kepustakaan dengan pendekatan peraturan perundang-undangan, pendekatan konseptual, dan pendekatan komparatif. Hasil penelitian menunjukkan bahwa dari hasil evaluasi semua faktor yang mungkin mempengaruhi efektivitas pemeriksaan pajak, faktor organisasi, pemeriksa pajak, peraturan, dan dukungan manajemen dari Direktorat Jenderal Pajak telah memenuhi kriteria untuk terwujudnya pemeriksaan pajak yang efektif di Indonesia. Namun faktor wajib pajak, independensi organisasi dan kualitas pemeriksaan belum mendukung terwujudnya pemeriksaan pajak yang efektif di Indonesia. Kemudian jika dilihat dari tingkat kepatuhan wajib pajak sebagai indikator yang menunjukkan pemeriksaan pajak telah dijalankan secara efektif, pemeriksaan pajak di Indonesia belum efektif, karena tingkat kepatuhan dari wajib pajak hanya berada pada persentase 62,96\%
\end{abstract}


untuk wajib pajak badan dan wajib pajak orang pribadi non karyawan dan Rasio Kepatuhan Penyampaian SPT Tahunan PPh pada tahun 2017 hanya mencapai angka $72,64 \%$.

Kata kunci: official assessment system, self assessment system, kepatuhan pajak, pemeriksaan pajak.

\section{PENDAHULUAN}

Pajak merupakan sumber penerimaan utama bagi semua negara di seluruh dunia. Pendapatan yang diperoleh dari sektor pajak digunakan untuk membeli input yang penting guna menyediakan barang dan jasa yang disediakan pemerintah atau untuk mengalokasikan kembali daya beli di masyarakat (Hyman, 2011). Jadi pendapatan dari sektor pajak akan dipakai oleh pemerintah untuk menyediakan barang dan jasa untuk kepentingan masyarakat banyak atau meningkatkan daya beli masyarakat. Barang yang disediakan oleh pemerintah dapat berupa peralatan pertanian dan perikanan yang diberikan kepada kelompok petani dan nelayan. Jasa yang disediakan pemerintah berupa pemberian layanan kesehatan dan pendidikan gratis kepada kelompok masyarakat tidak mampu yang membutuhkan. Di samping itu untuk menaikkan daya beli masyarakat pemerintah dapat memberikan bantuan dana langsung tunai atau penjualan beras atau bahan pokok murah yang disubsidi. Pajak juga sering disebut sebagai alat untuk redistribusi atau pengalihan sebagian pendapatan dari kelompok masyarakat yang berpenghasilan tinggi kepada kelompok masyarakat yang berpenghasilan sangat rendah.

Untuk memungut pajak dari masyarakat, otoritas pajak setiap negara dapat menerapkan sistem pemu- ngutan yang berbeda-beda antar satu otoritas pajak dengan otoritas pajak di negara lainnya. Secara umum ada 3 sistem pemungutan pajak yang dapat digunakan oleh otoritas pajak di setiap negara, yaitu official assessment system, self assessment system, dan witholding system. Pada official assessment system besarnya pajak yang harus dibayar oleh wajib pajak akan dihitung dan ditentukan oleh otoritas pajak berdasarkan data yang diberikan oleh wajib pajak. Jadi di sini otoritas pajak harus proaktif di dalam usaha memungut pajak dari wajib pajak. Sedangkan self assessment system akan memberikan kewenangan kepada wajib pajak untuk menghitung, menyetorkan, dan melaporkan sendiri pajak yang menjadi kewajibannya. Pada sistem ini wajib pajak yang harus proaktif untuk memenuhi kewajiban perpajakannya. Untuk sistem yang ketiga yaitu witholding system akan menggunakan pihak ketiga untuk terlibat di dalam memungut dan memotong pajak dari pihak-pihak yang menerima penghasilan dari pihak ketiga tersebut. Otoritas pajak di setiap negara harus memilih salah satu sistem pemungutan pajak utama yang akan digunakan antara official assessment system atau self assessment system. Sedangkan witholding system biasanya hanya dipakai sebagai sistem tambahan untuk melengkapi salah satu sistem pemungutan pajak utama yang 
telah dipilih oleh suatu negara untuk diterapkan.

Jika otoritas pajak dari suatu negara menggunakan official assessment system, maka berarti otoritas pajak di negara tersebut akan mempunyai pekerjaan yang cukup banyak untuk menghitung satu demi satu utang pajak dari masing-masing wajib pajak. Official assessment system akan cocok diterapkan jika tingkat pendidikan, pengetahuan dan wawasan dari masyarakatnya masih tergolong rendah serta jumlah penduduknya relatif tidak terlalu banyak. Jika tingkat pendidikan, pengetahuan, dan wawasan dari masyarakat masih rendah, maka akan sulit untuk menerapkan self assessment system. Sebaliknya jika tingkat pendidikan, pengetahuan, dan wawasan dari masyarakat sudah relatif tinggi dan jumlah penduduknya besar, maka penerapan self assessment system akan sangat membantu otoritas pajak di negara tersebut.

Dari kedua sistem pemungutan pajak yaitu official assessment system atau self assessment system, otoritas pajak di banyak negara umumnya menggunakan self assessment system. Hal ini karena tingkat pendidikan, pengetahuan, dan wawasan masyarakat negara-negara di dunia sudah cukup maju. Di samping itu penggunaan self assessment system lebih mudah, praktis, dan akan banyak mengurangi beban pekerjaan dari otoritas pajak yang secara otomatis juga mengurangi beban biaya operasional otoritas pajak.

Walaupun self assessment system mempunyai banyak kelebihan dibandingkan dengan official assessment system, namun self assessment system juga mempunyai kelemahan terkait dengan tingkat kepatuhan dari wajib pajak. Jika wajib pajaknya secara umum mempunyai tingkat kepatuhan yang rendah untuk membayar pajak, maka implementasi self assessment system sering mengalami kegagalan dalam memenuhi target pendapatan pemasukan dari sektor pajak. Untuk mengurangi dampak negatif dari self assessment system, maka otoritas pajak harus secara rutin melakukan tindakan pemeriksaan pajak guna menguji kepatuhan dari wajib pajak, khususnya untuk menekan praktik tax evasion dan tax avoidance dari wajib pajak. Adanya tindakan pemeriksaan pajak yang dilakukan oleh otoritas pajak akan mempunyai efek deterent praktik tax evasion dan tax avoidance dari wajib pajak.

Salah satu pilar yang penting dalam praktik self assessment system adalah tindakan pemeriksaan pajak. Agar tujuan dari pemeriksaan pajak menguji kepatuhan wajib pajak dapat tercapai, maka tindakan pemeriksaan pajak harus dapat dilaksanakan secara profesional dan proporsional. Pemeriksa pajak tidak boleh melakukan tindakan yang terlalu berlebihan, apalagi sampai mencari-cari kesalahan wajib pajak. Seluruh aparatur dari otoritas pajak harus selalu berpegangan pada prinsip bahwa pemeriksaan pajak diibaratkan hanya untuk mengambil telur dari ayam, bukan untuk memotong ayamnya. Karena jika ayamnya dipotong, maka ayamnya tidak akan dapat menghasilkan telur lagi. Pemeriksaan pajak juga tidak dimaksudkan untuk mematikan usaha dari wajib pajak dalam memperoleh penghasilan, tetapi hanya mengambil sebagian penghasilan wajib pajak yang menjadi hak dari negara dalam bentuk pajak. Pemeriksaan pajak yang dilakukan secara sembarangan, tidak bijaksana, dan terlalu memaksakan hasil pemeriksaan 
pajak untuk memenuhi target pemasukan pajak dapat menyebabkan sistem perpajakan terganggu dan memberikan legalitas yang buruk terhadap pemerintah, khususnya otoritas pajak.

Otoritas pajak harus mampu melaksanakan pemeriksaan secara efektif untuk mencapai tujuan pemeriksaan. Menurut Chalu and Mzee (2018) ada beberapa hal yang perlu diperhatikan untuk mencapai tujuan suatu pemeriksaan pajak yang efektif dan dapat digolongkan ke dalam 4 kategori. Keempat kategori itu, yaitu: kategori organisasi, kategori pemeriksa pajak, kategori wajib pajak, kategori peraturan. Sedangkan menurut Ayalew (2014) ada 5 faktor yang saling mempengaruhi efektivitas pemeriksaan pajak, yaitu: kualitas pemeriksaan, dukungan manajemen, pengaturan organisasi, atribut wajib pajak, dan independensi organisasi.

Pada tahun 1983 Indonesia melakukan reformasi perpajakan. Saat itu Pemerintah Indonesia menerbitkan 3 paket Undang-Undang Perpajakan, yaitu Undang-Undang tentang Ketentuan Umum dan Tata Cara Perpajakan, Undang-Undang tentang Pajak Penghasilan (PPh), dan Undang-Undang tentang Pajak Pertambahan Nilai (PPN) dan Pajak Penjualan atas Barang Mewah (PPnBM). Sistem pemungutan pajak yang sebelumnya menggunakan official assessment system diubah menjadi self assessment system. Self assessment system diberlakukan untuk pemungutan Pajak Penghasilan (PPh), Pajak Pertambahan Nilai (PPN) dan Pajak Penjualan atas Barang Mewah (PPnBM).

Undang-Undang Nomor 6 Tahun 1983 tentang Ketentuan Umum dan Tata Cara Perpajakan yang telah diubah beberapa kali terakhir dengan
Undang-Undang Nomor 16 Tahun 2009 pasal 29 ayat (1) menyatakan Direktur Jenderal Pajak berwenang melakukan pemeriksaan untuk menguji kepatuhan pemenuhan kewajiban perpajakan wajib pajak dan untuk tujuan lain dalam rangka melaksanakan ketentuan peraturan perundangundangan perpajakan. Ketentuan dari pasal 29 ayat (1) ini menunjukkan pemeriksaan pajak merupakan salah satu pilar penting untuk menguji kepatuhan pemenuhan kewajiban perpajakan dan atau tujuan lain dalam implementasi self assessment system untuk pemungutan Pajak Penghasilan (PPh), Pajak Pertambahan Nilai (PPN), dan Pajak Penjualan atas Barang Mewah (PPnBM) di Indonesia. Agar pelaksanaan kegiatan pemeriksaan dapat mencapai tujuan yang diinginkan, maka pelaksanaan tindakan pemeriksaan harus dilakukan secara efektif. Pada tulisan ini akan dilakukan evaluasi untuk menilai apakah kegiatan pemeriksaan pajak di Indonesia sudah dilaksanakan secara efektif berdasarkan konsep yang dikemukakan beberapa ahli, terutama oleh Chalu and Mzee (2018) dan Ayalew (2014).

\section{TINJAUAN PUSTAKA \\ Kepatuhan Wajib Pajak}

Umumnya perilaku setiap wajib pajak untuk menjadi wajib pajak yang patuh atau tidak patuh tergantung pada 3 hal. Pertama, berapa jumlah penghematan pajak yang diperoleh dari sikap tidak patuhnya tersebut. Semakin besar jumlah penghematan pajak yang didapat dari sikap tidak patuh tersebut, semakin tinggi tingkat kecenderungan wajib pajak tersebut untuk menjadi tidak patuh. Tetapi semakin kecil jumlah penghematan pajak yang didapat dari sikap tidak patuh tersebut, se- 
makin rendah tingkat kecenderungan wajib pajak tersebut untuk menjadi tidak patuh. Kedua, besarnya denda atau sanksi administrasi dan atau sanksi pidana yang dapat dikenakan terhadap wajib pajak yang diketahui tidak patuh di dalam memenuhi kewajiban perpajakannya. Semakin tinggi sanksi administrasi dan atau semakin berat sanksi pidana yang dapat dikenakan terhadap wajib pajak yang tidak patuh, maka akan semakin rendah tingkat kecenderungan wajib pajak tersebut untuk menjadi tidak patuh. Tetapi semakin rendah sanksi administrasi dan atau semakin ringan sanksi pidana yang dapat dikenakan terhadap wajib pajak yang tidak patuh, maka akan semakin tinggi tingkat kecenderungan wajib pajak tersebut untuk menjadi tidak patuh. Ketiga, tingkat kemungkinan atau peluang sikap tidak patuh tersebut dideteksi oleh otoritas pajak. Semakin kecil tingkat kemungkinan sikap tidak patuh tersebut diketahui oleh otoritas pajak, maka akan semakin tinggi tingkat kecenderungan wajib pajak tersebut untuk menjadi tidak patuh. Sebaliknya semakin besar tingkat kemungkinan sikap tidak patuh tersebut diketahui oleh otoritas pajak, maka akan semakin rendah tingkat kecenderungan wajib pajak tersebut untuk menjadi tidak patuh.

Pemeriksaan pajak yang dilakukan secara rutin dan intensif akan dapat meningkatkan kemungkinan ketidakpatuhan dari wajib pajak diketahui oleh otoritas pajak. Pemeriksaan pajak yang dilakukan dengan frekuensi yang tinggi dan terperinci akan dengan mudah mengetahui wajib pajak yang tidak patuh. Sebaliknya jika pemeriksaan pajak dilakukan dengan frekuensi yang rendah dan secara umum saja, maka kemungkinan terdeteksinya wa- jib pajak yang tidak patuh semakin kecil.

Wajib pajak akan mempunyai tingkat ketidakpatuhan yang tinggi untuk memenuhi kewajiban perpajakannya, jika dari sikap tidak patuh tersebut wajib pajak akan mendapatkan penghematan pajak yang besar, dan sikap tidak patuhnya kecil kemungkinan untuk terdeteksi, serta hanya akan dikenakan sanksi administrasi atau sanksi pidana yang ringan jika sikap tidak patuh itu ditemukan oleh otoritas pajak. Sebaliknya wajib pajak akan mempunyai tingkat kepatuhan yang tinggi untuk memenuhi kewajiban perpajakannya, jika wajib pajak hanya akan mendapatkan penghematan pajak yang kecil jika bersikap tidak patuh, besar kemungkinan untuk terdeteksi bila wajib pajak bersikap tidak patuh, serta akan dikenakan sanksi administrasi atau sanksi pidana yang berat jika wajib pajak diketahui tidak patuh.

\section{Pemeriksaan Pajak}

OECD (2006) menyatakan pemeriksaan pajak adalah pemeriksaan untuk menentukan apakah wajib pajak telah dengan benar menilai dan melaporkan kewajiban pajaknya serta memenuhi kewajiban lainnya. Sedangkan ERCA (2010) mendefinisikan pemeriksaan pajak sebagai suatu kegiatan atau serangkaian kegiatan yang dilakukan oleh pemeriksa pajak untuk menentukan kewajiban pajak dari wajib pajak yang benar untuk periode akuntansi atau pajak tertentu, dengan memeriksa produk-produk organisasi wajib pajak dan catatan keuangan untuk menilai kepatuhan terhadap Undang-Undang Perpajakan dan memverifikasi kebenaran, kejujuran, keandalan, dan akurasi Surat Pemberitahuan Pajak dan laporan keuangan. Abebe 
(2018) menyatakan pemeriksaan pajak adalah pemeriksaan yang dilakukan untuk menentukan apakah wajib pajak telah melaporkan dengan benar kewajiban pajaknya dan memenuhi kewajiban lainnya.

Sen and Bala (2002) menyatakan pemeriksaan pajak adalah perpanjangan dari "fungsi membuktikan" dari audit keuangan historis. Pengertian ini timbul dari asumsi bahwa setiap wajib pajak akan menyusun laporan keuangan yang telah diaudit oleh auditor eksternal. Data dari laporan keuangan yang telah diaudit akan dipakai untuk penyusunan laporan pajak dalam bentuk Surat Pemberitahuan Pajak. Pemeriksanaan pajak dianggap sebagai kegiatan untuk membuktikan kebenaran data yang dilaporkan Surat Pemberitahuan Pajak yang diisi berdasarkan data dari laporan keuangan yang telah diaudit.

Menurut Kirchler (2007) pemeriksaan pajak adalah investigasi yang dilakukan oleh otoritas pajak untuk memverifikasi keakuratan pengembalian pajak dan upaya untuk mendeteksi ketidakpatuhan perilaku dan kegiatan. Namun peran pemeriksaan dalam administrasi perpajakan modern sudah berkembang, tidak hanya kegiatan memverifikasi kewajiban wajib pajak dan mendeteksi wajib pajak yang mempunyai ketidaksesuaian antara laporan pajaknya dengan dokumentasi pendukung (Ayalew, 2014).

Undang-Undang Nomor 6 Tahun 1983 tentang Ketentuan Umum dan Tata Cara Perpajakan yang telah diubah beberapa kali terakhir dengan Undang-Undang Nomor 16 Tahun 2009 pasal 1 angka 25 menyatakan pemeriksaan adalah serangkaian kegiatan menghimpun dan mengolah data, keterangan, dan atau bukti yang dilaksa- nakan secara objektif dan profesional berdasarkan suatu standar pemeriksaan untuk menguji kepatuhan pemenuhan kewajiban perpajakan dan atau untuk tujuan lain dalam rangka melaksanakan ketentuan peraturan perundang-undangan perpajakan.

Dari uraian tersebut di atas ada 2 hal penting yang didapat dari pengertian pemeriksaan pajak. Pertama yaitu pemeriksaan pajak dilakukan untuk menguji kepatuhan pemenuhan kewajiban perpajakan dan atau untuk tujuan lain dengan membuktikan kebenaran laporan pajak yang sudah disampaikan wajib pajak. Kedua yaitu pemeriksaan pajak dilaksanakan dengan berbagai cara dan teknik pemeriksaan berdasarkan suatu standar pemeriksaan.

Pemeriksaan pajak merupakan instrumen yang utama dalam pelaksanaan sistem pemungutan pajak self assessment. Dengan adanya pemeriksaan pajak diharapkan tingkat kepatuhan wajib pajak dapat dipertahankan atau bahkan ditingkatkan. Jika tidak ada pemeriksaan pajak, maka diperkirakan akan banyak wajib pajak yang tidak patuh, tidak melaporkan atau melaporkan pajak yang menjadi kewajibannya secara tidak jujur dan tidak benar.

\section{Efek Pemeriksaan Pajak}

Ketika wajib pajak diaudit akan ada dua efek yang ditimbulkan. Pertama, ketika wajib pajak diketahui tidak patuh, maka ada efek langsung bagi wajib pajak yaitu harus membayar pajak tambahan, termasuk denda dan pembayaran bunga, untuk tahun yang diperiksa. Kedua, ada kemungkinan efek tidak langsung dalam bentuk perubahan pada perilaku kepatuhan di masa depan. Tanggapan perilaku ini bisa terjadi dalam dua bentuk, 
yaitu: (1) perubahan perilaku dari wajib pajak yang diperiksa (kadang-kadang diberi label efek "korektif" atau "pencegahan"); dan (2) limpahan kepada pembayar pajak yang tidak diaudit, kadang-kadang dilabeli efek "pencegah” (Gemmell and Ratto, 2012).

Jadi pemeriksaan pajak akan memberikan efek langsung dan efek tidak langsung. Efek langsung ini bisa berupa efek korektif dan atau efek pencegahan. Efek korektif berhubungan dengan wajib pajak yang diperiksa, di mana jika dari hasil pemeriksaan ditemukan adanya pajak yang tidak dilaporkan atau belum dilaporkan sepenuhnya, maka wajib pajak harus membayar pajak yang tidak dibayar atau kurang dibayar tersebut beserta sanksi administrasinya termasuk bunga. Bila ditemukan adanya tindak pidana perpajakan, maka akan ada efek korektif berupa tuntutan pidana terhadap wajib pajak yang diperiksa. Efek pencegahan berhubungan dengan perubahan perilaku dari wajib pajak yang umumnya akan menjadi lebih patuh setelah mengalami proses pemeriksaan pajak. Jadi pemeriksaan pajak dapat memberikan efek jera kepada wajib pajak yang diperiksa, dan akan dapat merubah perilakunya menjadi lebih patuh untuk memenuhi kewajiban perpajakannya.

Efek tidak langsung dari pemeriksaan pajak dapat berupa memberi kesadaran dan kewaspadaan kepada wajib pajak bahwa jika dia bersikap tidak patuh untuk memenuhi kewajiban perpajakannya, maka sikap tidak patuh tersebut akan dapat dengan mudah diketahui oleh otoritas pajak yang akan melakukan tindakan pemeriksaan pajak secara berkala. Bila ketidakpatuhan dari wajib pajak tersebut diketahui oleh otoritas pajak melalui tindak- an pemeriksaan pajak, maka wajib pajak akan menanggung konsekuensi sikap tidak patuh tersebut berupa kewajiban membayar pajak yang tidak dibayar atau belum dibayar sepenuhnya ditambah sanksi administrasi termasuk bunga serta ada kemungkinan akan dikenakan tuntutan pidana jika ditemukan unsur tindak pidana perpajakan dalam sikap tidak patuh dari wajib pajak itu.

\section{Mengukur Indikator Pemeriksaan Pajak Efektif}

Chalu and Mzee (2018) berpendapat bahwa mengukur efektivitas pemeriksaan pajak sangat kompleks, karena terbatasnya konsensus mengenai indikator atau dimensi yang dipakai menilai pemeriksan pajak yang efektif dan metodologi yang dipakai untuk menilainya. Penelitian-penelitian yang telah dilakukan menghasilkan pendapat yang berbeda-beda antara satu peneliti dengan peneliti lainnya.

Kastlunger et al. (2009) mempertimbangkan kepatuhan pajak (tanpa ada tax evasion) sebagai suatu indikator dari pemeriksaan pajak yang efektif. Isa and Pope (2011) berpendapat bahwa pemeriksaan pajak yang efektif dapat diukur dari peningkatan kepatuhan pajak sukarela, dengan memastikan bahwa wajib pajak mematuhi Undang-Undang dan Peraturan Perpajakan saat ini, memungkinkan terciptanya kondisi pajak yang dapat mendidik wajib pajak, serta mengidentifikasi hal-hal untuk perbaikan pencatatan, dan Undang-Undang Perpajakan yang membutuhkan klarifikasi.

\section{Faktor-faktor yang Mempengaruhi Pemeriksaan Pajak Efektif}

Menurut Chalu and Mzee (2018) banyak faktor yang mempengaruhi 
efektivitas pemeriksaan pajak yang dikelompokkan ke dalam empat kategori, yaitu, organisasi, pemeriksa pajak, wajib pajak dan peraturan. Yang dimaksud organisasi di sini termasuk personil, budaya, teknologi, lingkungan dan dukungan manajemen. Untuk dapat melakukan pemeriksaan pajak yang efektif perlu tersedianya personil pemeriksa pajak yang cakap, tangguh, profesional dan berintegritas tinggi. Pemeriksa pajak yang cakap akan mampu melaksanakan kegiatan pemeriksaan dengan baik dan dapat menyelesaikan semua permasalahan yang ditemui di lapangan, karena sudah dibekali kemampuan teknis dan pengalaman yang memadai. Pemeriksa pajak yang tangguh akan mampu menghadapi segala tantangan, ancaman dan intimidasi yang mungkin dihadapi di dalam melakukan pemeriksaan. Pemeriksa pajak yang profesional akan memiliki sikap yang independen, objektif, mandiri dan dapat bekerjasama baik dengan wajib pajak dalam melaksanakan tugas-tugasnya serta dapat menunjukkan sikap dan perilaku yang menghargai hak, pendapat dan keterangan dari wajib pajak. Pemeriksa pajak yang berintegritas akan memiliki karakter jujur, bertanggungjawab serta tidak dapat dipengaruhi dengan imbalan apapun. Organisasi dari pemeriksa pajak yang tidak memiliki personil yang cakap, tangguh, profesional dan berintegritas tinggi akan sulit untuk melakukan pemeriksaan yang efektif.

Yang dimaksud budaya di sini adalah kebiasaan atau cara-cara bekerja, bersikap, berkomunikasi yang telah menjadi ciri khas dari organisasi di mana pemeriksa pajak berada. Budaya kerja yang rajin, disiplin, gigih, ulet, dapat beradaptasi dan bekerjasama dengan baik harus menjadi acuan bagi pemeriksa pajak. Jika organisasi dari pemeriksa pajak tidak memiliki budaya organisasi yang baik, misalnya personilnya cenderung malas, tidak disiplin, sulit beradaptasi dan berkerjasama, baik dengan sesama rekan kerja maupun wajib pajak, maka sulit bagi organisasi untuk melaksanakan pekerjaan pemeriksaan secara efektif.

Yang dimaksud dengan teknologi di sini, yaitu organisasi dari pemeriksa pajak harus mengadopsi dan mengaplikasikan segala perkembangan teknologi untuk memudahkan pekerjaan personil dari otoritas pajak dan juga memudahkan wajib pajak untuk memenuhi kewajiban perpajakannya. Penggunaan teknologi informasi dan komunikasi dalam penanganan administrasi perpajakan akan membantu otoritas pajak dalam melakukan pemantauan aktivitas penyetoran dan pelaporan pajak oleh wajib pajak. Di samping itu dengan mengaplikasikan teknologi informasi semua data dari wajib pajak akan tersimpan di server otoritas pajak dan ini memudahkan untuk mengetahui track record dari wajib pajak. Hal ini semua akan membantu pemeriksa pajak di dalam melakukan pemeriksaan, karena sudah memiliki data awal mengenai wajib pajak. Pemanfaatan teknologi informasi dalam proses pemeriksaan juga mempermudah tugas dari pemeriksa pajak. Dengan dukungan teknologi, maka proses pemeriksaan akan dapat berjalan secara lebih efektif.

Pemeriksaaan pajak akan dapat dilakukan secara efektif dalam kondisi lingkungan organisasi yang kondusif. Pemeriksaan pajak akan dapat berjalan secara efektif pada kondisi lingkungan organisasi, di mana semua elemen memberikan dukungan baik langsung maupun tidak langsung untuk keber- 
hasilan tugas dari pemeriksa pajak. Misalkan pada saat pemeriksa pajak membutuhkan data tertentu mengenai wajib pajak yang diperiksa, data tersebut dengan cepat dapat diperoleh karena adanya dukungan penuh dari bagian sistem informasi.

Manajemen sebagai pihak yang bertanggung jawab terhadap kinerja otoritas pajak secara keseluruhan harus dapat memberikan dukungan penuh terhadap pekerjaan yang dilakukan oleh pemeriksa pajak, termasuk melindungi pemeriksa pajak dari berbagai ancaman, tantangan atau semacamnya yang berasal dari berbagai pihak. Dengan adanya dukungan yang penuh dari manajemen, maka pemeriksa pajak dapat bekerja dengan penuh keyakinan dan tidak ragu-ragu, karena apa yang dikerjakan akan didukung sepenuhnya oleh pihak manajemen. Hal ini akan menyebabkan pemeriksaan dapat dilakukan secara efektif.

Kategori kedua faktor yang mempengaruhi efektivitas pemeriksaan pajak adalah pemeriksa pajak. Pemeriksa pajak harus memiliki kemampuan terintegrasi yang berhubungan dengan penguasaan ilmu, keterampilan dan wawasan berkaitan dengan audit, akuntansi, pajak, keuangan, hukum, ekonomi, bisnis, serta teknologi informasi dan komunikasi. Di samping itu dari sudut attitude, pemeriksa harus dapat bersikap sopan, jujur, disiplin, dapat bekerjasama, mampu beradaptasi, dan berintegritas tinggi. Otoritas pajak harus mengelompokkan para pemeriksa pajak yang dikoordinir agar memiliki spesialisasi pemeriksaan pajak pada jenis usaha, bisnis atau industri tertentu. Hal ini dibutuhkan agar setiap pemeriksa pajak akan mempunyai spesialisasi keahlian khusus atau kepakaran untuk memeriksa pajak jenis usaha, bisnis atau industri tertentu. Dengan demikian penentuan penugasan pemeriksa pajak untuk memeriksa wajib pajak dapat dilakukan dengan mudah disesuaikan dengan jenis usaha, bisnis atau industri dari wajib pajak yang akan diperiksa.

Agar kemampuan yang dimiliki oleh pemeriksa pajak tidak ketinggalan dan tetap sesuai dengan kondisi terkini dari perkembangan dunia bisnis dan industri, maka pihak manajemen organisasi pemeriksa pajak secara berkala harus mengikutsertakan para pemeriksa pajak untuk mengikuti berbagai kegiatan guna memperbahurui dan meningkatkan penguasaan ilmu dan keterampilan yang dimiliki oleh para pemeriksanya dalam bentuk seminar, lokakarya, workshop atau sejenisnya, baik yang diadakan di internal organisasi maupun di luar organisasi. Pemeriksa pajak yang memiliki penguasaan ilmu, keterampilan yang tinggi dan wawasan yang luas pada bidangbidang audit, akuntansi, pajak, keuangan, hukum, ekonomi, bisnis, teknologi informasi dan komunikasi, serta memiliki attitude yang baik akan mendukung terciptanya pemeriksaan pajak yang efektif.

Kategori ketiga faktor yang menentukan efektivitas pemeriksaan pajak adalah wajib pajak. Jika wajib pajak yang diperiksa adalah wajib pajak terdidik dengan tingkat pendidikan yang tinggi, memahami aturan pajak, serta mempunyai tingkat kepatuhan dan keperdulian yang tinggi untuk memenuhi kewajiban perpajakannya, maka pemeriksaan pajak akan dapat dilakukan secara lebih efektif. Sebaliknya bila wajib pajak yang diperiksa adalah wajib pajak dengan tingkat pendidikan rendah atau kurang terdidik, tidak memahami aturan pajak, 
serta memiliki tingkat kepatuhan yang rendah untuk memenuhi kewajiban perpajakannya, maka pemeriksaan pajak yang dilakukan akan kurang efektif. Wajib pajak dengan tingkat kepatuhan pajak yang tinggi selain taat dalam membayar dan melaporkan pajak, juga umumnya sangat perduli dalam melakukan administrasi untuk mencatat kegiatan usahanya serta mengarsipkannya beserta bukti-bukti pendukungnya, sehingga memudahkan pemeriksa pajak untuk melakukan pemeriksaan pajak yang efektif. Sebaliknya wajib pajak yang memiliki kepatuhan pajak yang rendah akan cenderung tidak memiliki catatan yang lengkap dan bukti-bukti pendukung mengenai kegiatan usahanya akan mempersulit pemeriksa pajak untuk melakukan pemeriksaan pajak yang efektif.

Kategori keempat faktor yang mempengaruhi efektivitas pemeriksaan pajak adalah peraturan. Peraturan yang dimaksud di sini adalah peraturan pajak. Pemeriksaan pajak dapat berjalan secara efektif, jika peraturan pajak yang dibuat bersifat sederhana, mudah dimengerti dan dipahami. Peraturan pajak di sini meliputi UndangUndang Perpajakan dan peraturan pelaksana lainnya. Peraturan pajak yang kompleks, susah dimengerti dan dipahami serta bisa menimbulkan multi tafsir dan mengandung banyak celah kelemahan (loop holes) akan mempersulit pemeriksa pajak. Peraturan perpajakan yang disusun harus mampu diaplikasikan dengan baik serta memiliki seminimal mungkin celah kelemahan (loop holes) yang dapat dimanfaatkan oleh wajib pajak untuk mengurangi jumlah pajak yang menjadi kewajibannya, baik dengan cara-cara yang tergolong tax avoidance maupun tax evasion. Peraturan pajak yang disusun dengan baik: sederhana, jelas, tidak ambigu atau multi tafsir serta dapat diaplikasikan dalam berbagai situasi dan kondisi yang ada akan sangat membantu terselenggaranya pemeriksaan pajak yang efektif.

Sedangkan Ayalew (2014) menyatakan efektivitas pemeriksaan pajak banyak ditentukan oleh 5 faktor yang saling mempengaruhi, yaitu: kualitas pemeriksaan, dukungan manajemen, pengaturan organisasi, atribut dari pihak yang diperiksa dan independensi dari organisasi. Kualitas pemeriksaan akan tergantung pada keahlian dari staf pemeriksa, perencanaan, pekerjaan lapangan dan review kualitas, komunikasi pemeriksaan. Apabila pemeriksaan pajak dilakukan oleh staf pemeriksa pajak yang ahli dan berpengalaman, direncanakan dengan baik dan pekerjaan pemeriksaan lapangan dimonitor dan dikontrol dengan baik, maka pemeriksaan pajak akan dapat berjalan secara efektif. Untuk dapat melakukan pemeriksaan pajak dengan baik, perlu dukungan dari manajemen. Manajemen harus sepenuhnya memberikan dukungan kepada staf pemeriksa pajak. Adanya dukungan yang total secara proporsional dari manajemen akan mendukung pemeriksa pajak untuk dapat melakukan pemeriksaan pajak yang efektif.

Pemeriksaan yang efektif juga dipengaruhi oleh pengaturan organisasi. Pengaturan organisasi terdiri dari status pemeriksa pajak dalam struktur organisasi otoritas pajak, anggaran untuk kegiatan pemeriksaan pajak, adanya kriteria yang jelas untuk mengevaluasi setiap proses pemeriksaan pajak. Pemeriksaan pajak akan dapat dilakukan secara efektif jika posisi dari pemeriksa pajak dalam struktur orga- 
nisasi otoritas pajak bersifat sangat strategis, memiliki anggaran yang cukup besar untuk melakukan kegiatan operasional pemeriksaan pajak serta ada mekanisme evaluasi yang transparan dan efektif terhadap kegiatan pemeriksaan pajak.

Pemeriksaan pajak dapat dilakukan secara efektif, jika wajib pajak yang diperiksa mempunyai tingkat kepatuhan pajak yang tinggi, serta mau bekerjasama untuk mendukung dan mempermudah pemeriksaan yang dilakukan pemeriksa pajak. Wajib pajak dengan tingkat kepatuhan pajak yang rendah serta tidak mau bekerjasama mendukung pemeriksa pajak dengan menyediakan dokumen-dokumen yang dibutuhkan secara lengkap akan menyebabkan pemeriksaan pajak tidak dapat dilaksanakan secara efektif.

Efektivitas pemeriksaan pajak juga sangat ditentukan oleh independensi dari organisasi pemeriksa pajak. Jadi organisasi yang mengelola pemeriksa pajak harus terpisah dengan organisasi yang melakukan operasional pemungutan pajak. Jika organisasi pemeriksa pajak berada di bawah satu manajemen dengan organisasi pemungut pajak, maka dikhawatirkan pemeriksa pajak menjadi tidak independen dalam melakukan pemeriksaan pajak.

Berdasarkan pendapat dari Chalu and Mzee (2018) dan Ayalew (2014) dapat disimpulkan faktor-faktor yang mempengaruhi efektivitas pemeriksaan pajak yaitu organisasi, independensi organisasi, wajib pajak, kualitas pemeriksaan, pemeriksa pajak, peraturan dan dukungan manajemen.

\section{METODE PENELITIAN}

Jenis penelitian ini adalah penelitian kepustakaan. Penelitian ini dilakukan dengan cara meneliti bahan pus- taka atau data sekunder. Penelitian ini menggunakan beberapa pendekatan, yaitu: pendekatan perundang-undangan (statute approach), pendekatan konseptual (conceptual approach), dan pendekatan komparatif (comparative approach).

Pendekatan peraturan perundang-undangan (statute approach) dilakukan dengan cara menelaah semua peraturan perundang-undangan yang berkaitan dengan isu yang sedang dibahas, yaitu menelaah peraturan perundang-undangan yang berhubungan atau ada kaitannya dengan pemeriksaan pajak. Pendekatan konseptual (conceptual approach) dilakukan dengan cara menelaah konsep-konsep yang dikemukakan oleh para ahli berkaitan dengan efektivitas pemeriksaan pajak.

Pendekatan komparatif (comparative approach) dilakukan dengan cara membandingkan peraturan mengenai pemeriksaan pajak di Indonesia beserta data-data sekunder dari laporan Direktorat Jenderal Pajak dengan konsep pemeriksaan pajak dari para ahli. Dari perbandingan peraturan beserta data-data sekunder dari laporan Direktorat Jenderal Pajak dengan konsep-konsep yang dikemukakan para ahli akan dilakukan penilaian apakah pemeriksaan pajak di Indonesia sudah berjalan secara efektif.

\section{Pemeriksaan Pajak di Indonesia}

Ketentuan pemeriksaan pajak di Indonesia diatur dengan Undang-Undang Nomor 6 Tahun 1983 tentang Ketentuan Umum dan Tata Cara Perpajakan yang telah diubah beberapa kali terakhir dengan Undang-Undang Nomor 16 Tahun 2009. Se-lanjutnya pemeriksaan pajak ini diatur lebih lanjut dengan Peraturan Menteri 
Keuangan Nomor 17/PMK.03/2013 tanggal 7 Januari 2013 tentang Tata Cara Pemeriksaan sebagaimana telah diubah dengan Peraturan Menteri Keuangan Nomor 184/PMK.03/2015 tanggal 30 September 2015. Petunjuk pelaksanaan dari Peraturan Menteri Keuangan ini diatur lebih lanjut dalam Surat Edaran Direktur Jenderal Pajak Nomor SE-15/PJ/2018 tanggal 13 Agustus 2018 tentang Kebijakan Pemeriksaan.

Undang-Undang Nomor 6 Tahun 1983 tentang Ketentuan Umum dan Tata Cara Perpajakan yang telah diubah beberapa kali terakhir dengan Undang-Undang Nomor 16 Tahun 2009 pasal 29 menyatakan Direktur Jenderal Pajak berwenang melakukan pemeriksaan untuk menguji kepatuhan pemenuhan kewajiban perpajakan wajib pajak dan untuk tujuan lain dalam rangka melaksanakan ketentuan peraturan perundang-undangan perpajakan. Hal ini menunjukkan bahwa pemeriksaan pajak di Indonesia dilakukan oleh organisasi Direktorat Jenderal Pajak yang dipimpin oleh Direktur Jenderal Pajak. Organisasi Direktorat Pajak ini mempunyai tugas melakukan pemungutan pajak sekaligus juga melaksanakan pemeriksaan pajak.

Bagi wajib pajak yang tidak setuju dengan hasil pemeriksaan pajak dapat melakukan upaya keberatan kepada Direktur Jenderal Pajak seperti yang diatur dalam pasal 24 ayat (1) Undang-Undang Nomor 6 Tahun 1983 tentang Ketentuan Umum dan Tata Cara Perpajakan yang telah diubah beberapa kali terakhir dengan UndangUndang Nomor 16 Tahun 2009. Pada pasal 24 ayat (1) Undang-Undang ini disebutkan bahwa wajib pajak dapat mengajukan keberatan hanya kepada
Direktur Jenderal Pajak atas suatu: (a) Surat Ketetapan Pajak Kurang Bayar; (b) Surat Ketetapan Pajak Kurang Bayar Tambahan; (c) Surat Ketetapan Pajak Nihil; (d) Surat Ketetapan Pajak Lebih Bayar; atau (e) pemotongan atau pemungutan pajak oleh pihak ketiga berdasarkan ketentuan peraturan perundang-undangan perpajakan yang berlaku.

Pada Direktorat Jenderal Pajak pusat, tugas pemeriksaan sekaligus penagihan dilaksanakan oleh Direktorat Pemeriksaan dan Penagihan. Kemudian ada 2 direktorat lagi yang memiliki tugas bersinggungan dengan proses pemeriksaan yaitu Direktorat Intelijen dan Penyidikan serta Direktorat Keberatan dan Banding. Direktorat Intelijen dan Penyidikan akan menangani wajib pajak yang diindikasikan melakukan tindak pidana di bidang perpajakan. Direktorat Keberatan dan Banding akan menangani wajib pajak yang akan mengajukan keberatan. Pada tingkat Kantor Wilayah ada Bidang Pemeriksaan, Penyidikan dan Penagihan Pajak yang akan menangani masalah pemeriksaan, penyidikan dan penagihan pajak. Untuk penanganan keberatan ada Bidang Pengurangan, Keberatan dan Banding. Pada tingkat Kantor Pelayanan Pajak Wajib Pajak Besar, Madya dan Pratama yang akan menangani masalah pemeriksaan pajak adalah Seksi Pemeriksaan.

Peraturan Menteri Keuangan Nomor 17/PMK.03/2013 tanggal 7 Januari 2013 tentang Tata Cara Pemeriksaan sebagaimana telah diubah dengan Peraturan Menteri Keuangan Nomor 184/PMK.03/2015 tanggal 30 September 2015 pasal 6 ayat (1), (2) dan (3) menyatakan pemeriksaan untuk menguji kepatuhan pemenuhan kewajiban perpajakan harus dilaksanakan 
sesuai dengan standar pemeriksaan yang digunakan sebagai ukuran mutu pemeriksaan dan merupakan capaian minimum yang harus dicapai dalam melaksanakan pemeriksaan. Standar pemeriksaan meliputi standar umum pemeriksaan, standar pelaksanaan pemeriksaan, dan standar pelaporan hasil pemeriksaan.

Surat Edaran Direktur Jenderal Pajak Nomor SE-15/PJ/2018 tanggal 13 Agustus 2018 tentang Kebijakan Pemeriksaan menyatakan dalam rangka pemilihan wajib pajak yang menjadi prioritas pemeriksaan dengan lebih objektif dan tepat sasaran, optimalisasi kinerja sumber daya manusia pemeriksa pajak, perbaikan peraturan perpajakan di bidang pemeriksaan, serta sejalan dengan arah reformasi perpajakan yang sedang dilakukan Direktorat Jenderal Pajak, diperlukan revitalisasi proses bisnis pemeriksaan yang telah ada. Revitalisasi proses bisnis pemeriksaan secara umum ditujukan untuk meningkatkan kuantitas dan kualitas pemeriksaan sehingga kegiatan pemeriksaan mampu mendorong pertumbuhan penerimaan pajak yang berkelanjutan, meningkatkan kepatuhan wajib pajak yang berkelanjutan (sustainable compliance), mencegah praktik penghindaran pajak oleh wajib pajak, serta mencapai pemeriksaan yang efektif.

Ketentuan dalam Surat Edaran ini menegaskan bahwa pemeriksaan hanya dilakukan terhadap wajib pajak yang termasuk dalam Daftar Sasaran Prioritas Pemeriksaan (DSPP) yang disusun oleh Komite Perencanaan Pemeriksaan baik di tingkat pusat maupun di tingkat Kantor Wilayah. Jadi Kantor Pelayanan Pajak tidak dapat dengan serta merta melakukan tindakan pemeriksaan terhadap wajib pa- jak yang tidak masuk dalam Daftar Sasaran Prioritas Pemeriksaan (DSPP). Dengan adanya aturan ini, diharapkan proses pelaksanaan pemeriksaan pajak yang dilakukan oleh Direktorat Jenderal Pajak akan dapat berjalan secara efektif, karena wajib pajak yang akan diperiksa sudah ditentukan terlebih dahulu berdasarkan Daftar Sasaran Prioritas Penggalian Potensi (DSP3) yang disusun berdasarkan kegiatan pengawasan dan pemeriksaan.

Menurut Direktorat Jenderal Pajak (2017: 9) hasil pelayanan dan penyuluhan dalam tahun 2017 adalah seperti berikut ini: (i) Indeks Kepuasaan Pengguna Layanan mencapai angka 4,27 (dari rentang 0,00 (tidak puas) 5,00 (sangat puas)); (ii) Indeks Efektivitas Penyuluhan mencapai angka 3,28 (dari rentang 0,00 (tidak efektif) 4,00 (efektif)); (iii) Persentase Panggilan Terjawab dalam layanan contact center Kring Pajak sebanyak 89,76\% terjawab. Dari sudut tata kelola organisasi pada tahun 2017 Direktorat Jenderal Pajak memiliki Nilai Kinerja Organisasi 105,37 dengan kategori Memenuhi Ekspektasi, Nilai Implementasi Akuntabilitas Kinerja Instansi Pemerintah 91,20 dengan kategori Memuaskan, Nilai Tingkat Kematangan Pengelolaan Organisasi dengan predikat A berkategori Sangat Baik (Direktorat Jenderal Pajak, 2017: 11).

Jumlah pegawai dari Direktorat Jenderal Pajak pada tahun 2017 sebanyak 43.052 orang, di mana 5.184 orang di antaranya merupakan pemeriksa pajak (Direktorat Jenderal Pajak, 2017: 51-53). Hal ini menunjukkan bahwa jumlah pemeriksa pajak sebanyak 12,04\% dari total pegawai Direktorat Jenderal Pajak. Data-data lain yang berhubungan dengan sumber daya manusia dari Direktorat Jenderal 
Pajak pada tahun 2017 adalah sebagai berikut: (i) pendidikan dan pelatihan yang telah diadakan sebanyak 501 kegiatan diklat yang diikuti oleh 20.652 pegawai; (ii) jumlah penugasan pegawai yang mengikuti tugas belajar sebanyak 440 pegawai; (iii) persentase pegawai yang memenuhi standar jam latihan sebanyak 91,40\%; (iv) beban kerja sebanyak 70.077.044 jam kerja (Direktorat Jenderal Pajak, 2017: 11). Pengembangan sumber daya aparatur di Direktorat Jenderal Pajak secara menyeluruh diarahkan untuk memastikan terselenggaranya organisasi yang fit for purpose serta tersedianya sumber daya manusia yang kompetitif dalam rangka mendukung tercapainya tujuan Direktorat Jenderal Pajak (Direktorat Jenderal Pajak, 2017: 27).

Administrasi perpajakan yang dilaksanakan pada Direktorat Jenderal Pajak sebagian besar sudah dilakukan dengan memanfaatkan teknologi informasi dan komunikasi. Pemanfaatan teknologi informasi dan komunikasi telah mampu memberikan banyak kemudahan kepada Direktorat Jenderal Pajak dan wajib pajak. Wajib pajak dengan mudah dapat melakukan penerbitan faktur pajak melalui fasilitas e-Faktur, pembayaran pajak melalui fasilitas e-billing dan pelaporan pajak (penyampaian SPT Masa dan SPT tahunan) melalui fasilitas e-Filing dan $e-S P T$. Dengan adanya sistem ini Direktorat Jenderal Pajak akan memiliki database lengkap dari semua wajib pajak beserta segala aktivitasnya yang berkaitan dengan pemenuhan kewajiban perpajakan. Hal ini akan sangat membantu dan mempermudah proses pemeriksaan pajak, karena pemeriksa pajak akan memiliki data yang lengkap berkaitan dengan wajib pajak yang diperiksa.
Pada tahun 2013 jumlah wajib pajak sebanyak 28.004.218 dengan Rasio Kepatuhan Penyampaian SPT Tahunan PPh sebesar 60,86\% (Direktorat Jenderal Pajak, 2013: 3). Pada tahun 2014 jumlah wajib pajak sebanyak 30.574.428 dengan Rasio Kepatuhan Penyampaian SPT Tahunan PPh sebesar 58,87\% (Direktorat Jenderal Pajak, 2014: 14). Pada tahun 2015 jumlah wajib pajak sebanyak 33.336.122 dengan Rasio Kepatuhan Penyampaian SPT Tahunan PPh sebesar 60,42\% (Direktorat Jenderal Pajak, 2015: 3). Pada tahun 2016 jumlah wajib pajak sebesar 36.446.616 dengan Rasio Kepatuhan Penyampaian SPT Tahunan PPh sebesar 60,82\% (Direktorat Jenderal Pajak, 2016: 4). Tahun 2017 menunjukkan jumlah wajib pajak sebanyak 39.151.603 dengan Rasio Kepatuhan Penyampaian SPT Tahunan PPh sebesar 72,64\% (Direktorat Jenderal Pajak, 2017: 9). Persentase tingkat kepatuhan formal wajib pajak badan dan wajib pajak orang pribadi non karyawan sebesar 62,96\% dan persentase pertumbuhan jumlah wajib pajak badan dan wajib pajak orang pribadi non karyawan yang melakukan pembayaran sebesar 32,73\% (Direktorat Jenderal Pajak, 2017: 58).

Penerimaan pajak yang diperoleh dari pemeriksaan pajak dalam tahun 2013 sebesar Rp. 20,74 triliun atau sebesar 2,25\% dari total penerimaan pajak Rp. 921,398 triliun (Direktorat Jenderal Pajak, 2013: 3-4). Penerimaan pajak yang diperoleh dari pemeriksaan pajak dalam tahun 2014 sebesar Rp. 24,47 triliun atau sebesar 2,48\% dari total penerimaan pajak Rp. 985,13 triliun (Direktorat Jenderal Pajak, 2014: 3-4). Penerimaan pajak yang diperoleh dari pemeriksaan pajak dalam tahun 2015 sebesar Rp. 38,74 
triliun atau sebesar 3,65\% dari total penerimaan pajak Rp. 1.060,86 triliun (Direktorat Jenderal Pajak, 2015: 3-4). Penerimaan pajak yang diperoleh dari pemeriksaan pajak dalam tahun 2016 sebesar Rp. 46,02 triliun atau sebesar 4,16\% dari total penerimaan pajak Rp. 1.105,97 triliun (Direktorat Jenderal Pajak, 2016: 4-5). Penerimaan pajak yang diperoleh dari pemeriksaan pajak dalam tahun 2017 sebesar Rp. 53,93 triliun atau sebesar 4,69\% dari total penerimaan pajak Rp. 1.151,03 triliun (Direktorat Jenderal Pajak, 2017: 810).

Pada tahun 2013 banding yang dimenangkan oleh Direktorat Jenderal Pajak sebesar 31,25\% (Direktorat Jenderal Pajak, 2013: 5). Pada tahun 2014 banding yang dimenangkan oleh Direktorat Jenderal Pajak sebesar 29,10\% (Direktorat Jenderal Pajak, 2014: 4). Pada tahun 2015 banding yang dimenangkan oleh Direktorat Jenderal Pajak sebesar 32,52\% (Direktorat Jenderal Pajak, 2015: 4). Pada tahun 2016 banding yang dimenangkan oleh Direktorat Jenderal Pajak sebesar 36,42\% (Direktorat Jenderal Pajak, 2016: 5). Pada tahun 2017 banding yang dimenangkan oleh Direktorat Jenderal Pajak sebesar 40,32\% (Direktorat Jenderal Pajak, 2017: 10).

\section{PEMBAHASAN}

Secara teori berdasarkan penggabungan pendapat dari Chalu and Mzee (2018) dan Ayalew (2014) ada 6 faktor yang mempengaruhi efektivitas pemeriksaan pajak, yaitu organisasi, independensi organisasi, wajib pajak, kualitas pemeriksaan, pemeriksa pajak, peraturan, dan dukungan manajemen. Secara umum dapat dikatakan bahwa pemeriksaan pajak akan dapat berjalan secara efektif bila 7 faktor tersebut menunjukkan kondisi yang mendukung.

Dari sudut organisasi, pemeriksaan pajak di Indonesia sudah didukung oleh personil pemeriksa pajak yang cakap, tangguh, profesional, dan berintegritas tinggi. Sumber daya manusia di Direktorat Jenderal Pajak, termasuk pemeriksa pajak pada tahun 2017 menjalani pendidikan dan pelatihan yang telah diadakan sebanyak 501 kegiatan diklat dan diikuti oleh 20.652 pegawai. Ada penugasan pegawai yang mengikuti tugas belajar sebanyak 440 pegawai. Besarnya persentase pegawai yang memenuhi standar jam latihan sebanyak 91,40\% dan beban kerja pegawai sebanyak 70.077.044 jam kerja. Dengan proses pendidikan, pelatihan, penugasan belajar, dan beban kerja yang sedemikian besar, maka kompetensi dari sumber daya manusia di Direktorat Jenderal Pajak termasuk pemeriksa pajak sudah tidak diragukan lagi. Beban kerja yang tinggi serta motivasi yang besar untuk selalu meningkatkan kemampuan dan keterampilan yang dimiliki melalui berbagai kegiatan pendidikan, pelatihan, dan tugas belajar merupakan budaya organisasi yang baik dan sangat positif dalam mendukung efektivitas pemeriksaan pajak.

Keberadaan pemeriksa pajak yang berada di semua tingkatan organisasi Direktorat Jenderal Pajak yaitu di Kantor Pusat, Kantor Wilayah, dan Kantor Pelayanan Pajak menunjukkan bahwa dari struktur organisasi yang ada sangat mendukung terlaksananya pemeriksaan pajak yang efektif. Hasil pelayanan dan penyuluhan dalam tahun 2017 yang ditunjukkan dari Indeks Kepuasaan Pengguna Layanan, Indeks Efektivitas Penyuluhan, dan Persentase Panggilan Terjawab dalam layanan 
contact center Kring Pajak yang tinggi menunjukkan kinerja layanan organisasi yang positif. Nilai Kinerja Organisasi dengan kategori Memenuhi Ekspektasi, Nilai Implementasi Akuntabilitas Kinerja Instansi Pemerintah dengan kategori Memuaskan, Nilai Tingkat Kematangan Pengelolaan Organisasi dengan predikat A berkategori Sangat Baik juga menunjukkan keberhasilan organisasi dalam bidang layanan. Semua prestasi dalam layanan dan penyuluhan menunjukkan keberhasilan dari Direktorat Jenderal Pajak dalam menerapkan tata kelola organisasi yang baik, berkualitas, dan dapat dipercaya. Kondisi ini juga akan mendukung terlaksananya pemeriksaan pajak yang efektif.

Keberhasilan organisasi Direktorat Jenderal Pajak dalam mengimplementasikan fasilitas e-Faktur untuk penerbitan faktur pajak digital, fasilitas e-billing untuk pembayaran pajak berbasis digital, dan fasilitas $e$-Filing dan $e$-SPT untuk pelaporan pajak berbasis digital sangat mendukung tersedianya database wajib pajak yang terintegrasi. Keberadaan database wajib pajak yang terintegrasi ini sangat membantu pemeriksa pajak dalam melakukan tugas pemeriksaan pajak secara efektif.

Secara umum lingkungan di mana pemeriksa pajak akan melakukan tugas pemeriksaan sangat mendukung. Di lingkungan internal kantor pemeriksa pajak, tersedia fasilitas ruangan yang aman dan nyaman, lengkap dengan peralatan kerja yang berbasis digital. Sedangkan di lingkungan eksternal yaitu di tempat wajib pajak, secara umum wajib pajak di Indonesia biasanya menghargai dan menghormati pemeriksa pajak serta akan memberikan tempat yang representatif dan kerjasama yang baik dengan pemeriksa pajak yang akan melakukan pemeriksaan lapangan. Kondisi ini semua akan mendukung pemeriksa pajak untuk dapat melakukan pemeriksaan pajak yang efektif.

Secara keseluruhan dari evaluasi pada faktor organisasi, pemeriksaan pajak yang dilakukan oleh Direktorat Jenderal Pajak akan dapat dilakukan secara efektif, karena semua hal yang berkaitan dengan faktor organisasi mendukung terwujudnya pemeriksaan pajak yang efektif. Kondisi organisasi yang mendukung pemeriksa pajak dalam melaksanakan tugasnya akan memudahkan pemeriksaan pajak dapat dilakukan secara efektif.

Jika ditinjau dari sudut independensi organisasi, pemeriksaan pajak di Indonesia tidak dilaksanakan oleh organisasi yang independen. Pemeriksaan pajak dilakukan oleh Direktorat Jenderal Pajak yang juga mempunyai tugas untuk memungut pajak dan melakukan administrasi perpajakan. Selama ini biasanya Direktorat Jenderal Pajak diberikan tugas memungut pajak dengan target capaian tertentu. Adanya target capaian pajak yang harus berhasil dipungut ini dimungkinkan akan memberikan beban tersendiri pada diri pemeriksa pajak untuk berusaha membantu memenuhi target penerimaan pajak yang harus dicapai Direktorat Jenderal Pajak. Hal ini dapat mempengaruhi independensi wajib pajak dalam melaksanakan tugas pemeriksaan pajak. Selama ini ada kesan wajib pajak lebih percaya pada proses banding di pengadilan pajak dari pada proses keberatan di Direktorat Jenderal Pajak. Ada anggapan dari wajib pajak, karena proses keberatan ditangani oleh pegawai di Direktorat Jenderal Pajak, maka hasilnya kemungkinan besar tidak ber- 
beda jauh dengan hasil dari pemeriksa pajak. Sedangkan proses banding karena ditangani oleh pengadilan pajak yang bersifat independen dan tidak ada hubungan dengan Direktorat Jenderal Pajak diyakini akan lebih objektif. Seharusnya pemeriksaan pajak dilakukan oleh organisasi independen di luar Direktorat Jenderal Pajak. Pemeriksaan pajak yang dilakukan oleh pemeriksa pajak dari Direktorat Jenderal Pajak akan menghambat terwujudnya pemeriksaan pajak yang efektif.

Jika dilihat dari data Direktorat Jenderal Pajak jumlah wajib pajak di Indonesia terus berkembang dari tahun ke tahun. Pada tahun 2013 jumlah wajib pajak sebanyak 28.004.218, yang berkembang menjadi 30.574.428 pada tahun 2014, berkembang lagi menjadi 33.336.122 pada tahun 2015, berkembang lagi menjadi 36.446.616 pada tahun 2016 dan terakhir menjadi 39.151.603 pada tahun 2017. Dari data tersebut nampak bahwa setiap tahun ada peningkatan jumlah wajib pajak yang merupakan salah satu petunjuk adanya peningkatan kepatuhan wajib pajak. Rasio Kepatuhan Penyampaian SPT Tahunan PPh pada tahun 2013, 2014, 2015, 2016 dan 2017 masingmasing sebesar $60,86 \%$, 58,87\%, $60,42 \%, 60,82 \%$, dan 72,64\%. Hal ini menunjukkan bahwa pada periode 2013-2017 secara umum Rasio Kepatuhan Penyampaian SPT Tahunan PPh berada di angka sekitar 60\%, kecuali pada tahun 2014 yang berada di angka 58,78\% dan di tahun 2017 berada di angka $72,64 \%$. Sedangkan persentase tingkat kepatuhan wajib pajak badan dan wajib pajak orang pribadi sebesar 62,96\%. Dari sudut jumlah wajib pajak terjadi peningkatan jumlah wajib pajak pada periode tahun 2013-2017 yang dapat diartikan adanya peningkatan kepatuhan dari wajib pajak. Sedangkan dari tingkat kepatuhan menyampaikan SPT Tahunan PPh pada periode 20132017 cenderung stagnan, kecuali pada tahun 2017 terjadi kenaikan. Jika dilihat data dari Direktorat Jenderal Pajak persentase tingkat kepatuhan formal wajib pajak sebesar 62,96\%. Berdasarkan data di atas nampak bahwa dari faktor wajib pajak tidak mendukung pemeriksaan pajak dapat dilakukan secara efektif, mengingat wajib pajak mempunyai tingkat kepatuhan yang masih rendah, di mana angka kepatuhan pajak formal hanya mencapai $62,96 \%$ dan tingkat kepatuhan penyampaian SPT Tahunan PPh paling tinggi hanya 72,64\%, walaupun ada penambahan jumlah wajib pajak setiap tahunnya.

Data dari Direktorat Jenderal Pajak menunjukkan bahwa pada tahun 2013, 2014, 2015, 2016, dan 2017 persentase banding yang dimenangkan oleh Direktorat Jenderal Pajak masingmasing 31,25\%, 29,10\%, 32,52\%, $36,42 \%$, dan $40,32 \%$. Walaupun pada periode tahun 2013-2017 dari tahun ke tahun ada kecenderungan peningkatan persentase banding yang dimenangkan oleh Direktorat Jenderal Pajak dengan persentase tertinggi pada tahun 2017 yang mencapai angka 40,32\%, tetapi keberhasilan kemenangan banding yang rata-rata kurang dari 50\% menunjukkan bahwa kualitas hasil pemeriksaan harus ditingkatkan lagi. Hal ini menunjukkan bahwa faktor kualitas pemeriksaan belum memberikan dukungan yang maksimal bagi terwujudnya suatu pemeriksaan yang efektif.

Pemeriksa pajak yang bertugas di Direktorat Jenderal Pajak pada tahun 2017 berjumlah 5.184 orang (12,04\% dari seluruh pegawai Direktorat Jenderal Pajak). Dengan total jum- 
lah wajib pajak sebesar 39.151.603, maka Rasio Pemeriksa Pajak Terhadap Total Wajib Pajak adalah 1: 7.552. Dari sudut kuantitas jumlah pemeriksa pajak sudah mencukupi kebutuhan tugas pemeriksaan pajak. Direktorat Jenderal Pajak pada tahun 2017 mengadakan sebanyak 501 kegiatan diklat yang melibatkan 20.652 orang pegawai $(47,97 \%$ dari seluruh pegawai) dan menugaskan 440 pegawai untuk tugas belajar. Pada tahun 2017 persentase pegawai yang memenuhi jam pelatihan sebanyak 91,40\% dengan beban jam kerja sebanyak 77.077.044 jam kerja. Hal ini semua menunjukkan bahwa pegawai Direktorat Jenderal Pajak, termasuk pemeriksa pajak dari segi kualitas tidak perlu diragukan lagi kompetensi dan kemampuannya. Jadi dilihat dari faktor pemeriksa pajak, tenaga pemeriksa pajak di Direktorat Jenderal Pajak sudah memenuhi persyaratan dari segi kuantitas maupun kualitas untuk terselenggaranya pemeriksaan yang efektif.

Dasar hukum pemeriksaan pajak yang utama terdapat di dalam UndangUndang Nomor 6 Tahun 1983 tentang Ketentuan Umum dan Tata Cara Perpajakan yang telah diubah beberapa kali terakhir dengan Undang-Undang Nomor 16 Tahun 2009, Peraturan Menteri Keuangan Nomor 17/ PMK. 03/2013 tanggal 7 Januari 2013 tentang Tata Cara Pemeriksaan sebagaimana telah diubah dengan Peraturan Menteri Keuangan Nomor 184/ PMK.03/2015 tanggal 30 September 2015 dan Surat Edaran Direktur Jenderal Pajak Nomor SE-15/PJ/2018 tanggal 13 Agustus 2018 tentang Kebijakan Pemeriksaan. Peraturan yang mengatur tentang pemeriksaan pajak sudah diatur dengan peraturan yang lengkap. Sumber hukumnya berupa
Undang-Undang, peraturan pelaksananya dalam bentuk Peraturan Menteri Keuangan dan petunjuk untuk pelaksanaan dalam bentuk Surat Edaran Direktur Jenderal Pajak. Peraturan pemeriksaan yang tercantum di dalam Undang-Undang, Peraturan Menteri Keuangan dan Surat Edaran Direktur Jenderal Pajak ini cukup sederhana, jelas, tidak multi tafsir dan menyeluruh serta memberikan hak dan kewajiban yang seimbang terhadap wajib pajak.

Kegiatan pemeriksaan pajak selain mengacu pada peraturan yang mengatur tentang pemeriksaan pajak, juga mengacu pada ketentuan dan peraturan pajak yang bersifat material. Ketentuan dan peraturan pajak bersifat material yang penting ada 2, yaitu UndangUndang Nomor 7 Tahun 1983 tentang Pajak Penghasilan yang telah diubah beberapa kali terakhir dengan UndangUndang Nomor 36 Tahun 2008 dan Undang-Undang Nomor 8 Tahun 1983 tentang Pajak Pertambahan Nilai Barang dan Jasa dan Pajak Penjualan atas Barang Mewah yang telah diubah beberapa kali terakhir dengan UndangUndang Nomor 42 Tahun 2009. Kedua Undang-Undang ini beserta peraturan pelaksananya secara umum sudah memenuhi kriteria peraturan yang sederhana, mudah dimengerti dan dipahami, tidak ambigu atau multi tafsir dengan tidak memiliki banyak celah kelemahan serta jauh dari kesan peraturan yang kompleks dan rumit. Jadi dari sudut peraturan perpajakan, kondisi yang ada sudah mendukung terwujudnya pemeriksaan yang efektif.

Manajemen dari Direktorat Jenderal Pajak telah memberikan perhatian dan dukungan yang sangat besar terhadap proses pemeriksaan pajak. Dari sudut organisasi, untuk membe- 
rikan dukungan yang maksimal, pada setiap jenjang di Direktorat Jenderal Pajak dari tingkat Kantor Pusat, tingkat Kantor Wilayah sampai dengan tingkat Kantor Pelayanan Pajak selalu ada unit yang menangani masalah pemeriksaan pajak. Di tingkat Kantor Pusat terdapat Direktorat Pemeriksaan dan Penagihan, di tingkat Kantor Wilayah terdapat Bidang Pemeriksaan, Penyidikan dan Penagihan Pajak serta di tingkat Kantor Pelayanan Pajak Wajib Pajak Besar, Madya dan Pratama ada Seksi Pemeriksaan. Dari sudut personil, dukungan manajemen terlihat dari segi kuantitas dan kualitas personil yang melakukan tugas pemeriksaan pajak. Ditinjau dari segi kuantitas, manajemen menyediakan jumlah personil pemeriksa pajak yang banyak, yaitu berjumlah sebesar 5.184 orang pada tahun 2017 atau sama dengan $12,04 \%$ dari seluruh pegawai yang ada di Direktorat Jenderal Pajak. Dari segi kualitas, manajemen telah mengadakan berbagai kegiatan diklat dan tugas belajar yang melibatkan banyak personil di Direktorat Jenderal Pajak, termasuk personil pemeriksa pajak. Dukungan lain dari manajemen berupa penyediaan berbagai fasilitas, dan keperluan dari pemeriksa pajak agar dapat melaksanakan tugasnya dengan baik.

Dari uraian di atas, nampaknya dari berbagai faktor yang mempengaruhi efektivitas pemeriksaan, faktor organisasi, pemeriksa pajak, peraturan dan dukungan manajemen dari Direktorat Jenderal Pajak telah memenuhi kriteria untuk terwujudnya pemeriksaan pajak yang efektif di Indonesia. Namun faktor wajib pajak, independensi organisasi dan kualitas pemeriksaan belum mendukung terwujudnya pemeriksaan pajak yang efektif. Jika dilihat dari indikator pemeriksaan pajak efektif seperti yang dikemukakan oleh Chalu and Mzee (2018), Kastlunger et al. (2009) dan Isa and Pope (2011), maka pemeriksaan pajak di Indonesia belum dapat dikatakan efektif, karena tingkat kepatuhan dari wajib pajak sebagai indikator pemeriksaan pajak efektif hanya berada pada persentase $62,96 \%$ untuk wajib pajak badan dan wajib pajak orang pribadi non karyawan. Demikian pula indikator lain untuk penilaian kepatuhan wajib pajak berupa Rasio Kepatuhan Penyampaian SPT Tahunan PPh pada tahun 2017 hanya sebesar 72,64\%.

\section{SIMPULAN}

Hasil penelitian menunjukkan bahwa secara keseluruhan dari hasil evaluasi semua faktor yang mungkin mempengaruhi efektivitas pemeriksaan pajak, faktor organisasi, pemeriksa pajak, peraturan dan dukungan manajemen dari Direktorat Jenderal Pajak telah memenuhi kriteria untuk terwujudnya pemeriksaan pajak yang efektif di Indonesia. Namun faktor wajib pajak, independensi organisasi dan kualitas pemeriksaan belum mendukung terwujudnya pemeriksaan pajak yang efektif.

Jika dilihat dari tingkat kepatuhan wajib pajak sebagai indikator yang menunjukkan pemeriksaan pajak telah dijalankan secara efektif, pemeriksaan pajak di Indonesia belum efektif, karena tingkat kepatuhan dari wajib pajak sebagai indikator pemeriksaan pajak efektif hanya berada pada persentase $62,96 \%$ untuk wajib pajak badan dan wajib pajak orang pribadi non karyawan dan Rasio Kepatuhan Penyampaian SPT Tahunan PPh pada tahun 2017 hanya mencapai angka 72,64\%. 


\section{SARAN}

1. Pemerintah Indonesia perlu mempertimbangkan untuk membentuk suatu badan yang khusus melakukan pemeriksaan pajak yang terlepas dari organisasi Direktorat Jenderal Pajak untuk menjamin independensi organisasi pemeriksa pajak.

2. Tingkat kepatuhan wajib pajak badan dan orang pribadi non karyawan yang hanya sebesar 62,96\% dan Rasio Kepatuhan Penyampaian SPT Tahunan PPh pada tahun 2017 yang hanya sebesar 72,64\% perlu mendapatkan perhatian dari Direktorat Jenderal Pajak untuk lebih ditingkatkan lagi pada masamasa yang akan datang.

3. Mengingat masih rendahnya jumlah persentase banding yang dimenangkan oleh Direktorat Jenderal Pajak yang masih di bawah 50\%, maka perlu adanya perbaikan terhadap kualitas pemeriksaan, sehingga jumlah persentase banding yang dimenangkan dapat mendekati jumlah 100\%.

4. Agar pemeriksa pajak dapat melakukan tugas pemeriksaan pajak secara objektif, maka setiap pemeriksa pajak tidak boleh diberikan target atau beban harus menghasilkan pemeriksaan pajak yang menyebabkan wajib pajak kurang bayar atau mengurangi klaim lebih bayar wajib pajak.

\section{DAFTAR KEPUSTAKAAN}

Abebe, Birhanu, 2018, Assessment of Tax Audit Practice: In The Case of Addis Ketema Sub-City, Thesis Submitted in Partial Fulfilment of The Requirements for The Degree of Masters in Accounting and Finance, St. Mary University,
School of Graduate Studies Department of Accounting and Finance.

Al_Frijat, Yaser Saleh, 2013, The Impact of Accounting Information Systems Used in The Income Tax Department on The Effectiveness of Tax Audit and Collection in Jordan, Journal of Emerging Trends in Economics and Management Sciences (JETEMS), Vol. 5, No. 1, page 19-25.

Ayalew, Elias, 2014, Factors Affecting Tax Audit Effectiveness: A Study on Category "A" Taxpayers in Bahir Dar City Administration Revenue Office, Thesis, Department Of Accounting \& Finance, College Of Business \& Economics, Bahir Dar Unversity.

Chalu, Henry and Hassan Mzee, 2018, Determinants of Tax Audit Effectiveness in Tanzania, Managerial Auditing Journal, Vol. 33, Issue 1, page 35-63.

Direktorat Jenderal Pajak, 2013, Laporan Tahunan 2013, Direktorat Jenderal Pajak, Kementerian Keuangan, Jakarta.

Direktorat Jenderal Pajak, 2014, Laporan Tahunan 2014, Direktorat Jenderal Pajak, Kementerian Keuangan, Jakarta.

Direktorat Jenderal Pajak, 2015, Laporan Tahunan 2015, Direktorat Jenderal Pajak, Kementerian Keuangan, Jakarta.

Direktorat Jenderal Pajak, 2016, Laporan Tahunan 2016, Direktorat Jenderal Pajak, Kementerian Keuangan, Jakarta. 
Direktorat Jenderal Pajak, 2017, Laporan Tahunan 2017, Direktorat Jenderal Pajak, Kementerian Keuangan, Jakarta.

Drogalas, George, Sorros Ioannis, Karagiorgou Dimitra, and Diavastis Ioannis, 2015, Tax Audit Effectiveness in Greek Firms: Tax Auditors' Perceptions, Journal of Accounting and Taxation, Vol. 7 (7), page 123130.

ERCA, 2010, Tax \& PCA Audit Policy \& Strategy, Tax Audit Directorate.

Gemmell, Norman and Marisa Ratto, 2012, Behavioral Responses to Taxpayer Audits: Evidence from Random Taxpayer Inquiries, National Tax Journal, Vol. 65, No. 1, page 33-58.

Hyman, D. N., 2011, Public Finance: A Contemporary Application of Theory to Policy, Joe Sabatino United States of America.

Isa, Khadijah and Jeff Pope, 2011, Corporate Tax Audits: Evidence from Malaysia, Global Review of Accounting and Finance, Vol. 2, No. 1, page 42-56.

Kastlunger, Barbara, Erich Kirchler, Luigi Mittone and Julia Pitters, 2009, Sequences of Audits, Tax Compliance, and Taxpaying Strategies, Journal of Economic Psychology, 30, page 405-418.

Kirchler, Erich, 2007, The Economic Psychology of Tax Behavior, Cambridge University Press, New York.

OECD, 2006, Strengthening Tax Audit Capabilities: General Principles and Approaches, Centre for Tax
Policy and Administration, OECD Publishing, Paris.

Peraturan Menteri Keuangan Nomor 17/PMK.03/2013 tanggal 7 Januari 2013 tentang Tata Cara Pemeriksaan sebagaimana telah diubah dengan Peraturan Menteri Keuangan Nomor 184/PMK.03/2015 tanggal 30 September 2015.

Sen, Dilip Kumar and Swapan Kumar Bala, 2002, Tax Audit: Bangladesh Panorama, Managerial Auditing Journal, Vol. 17, Issue 8, page 464477.

Surat Edaran Direktur Jenderal Pajak Nomor SE-15/PJ/2018 tanggal 13 Agustus 2018 tentang Kebijakan Pemeriksaan.

Undang-Undang Nomor 6 Tahun 1983 tentang Ketentuan Umum dan Tata Cara Perpajakan yang telah diubah beberapa kali terakhir dengan Undang-Undang Nomor 16 Tahun 2009.

Undang-Undang Nomor 7 Tahun 1983 tentang Pajak Penghasilan yang telah diubah beberapa kali terakhir dengan Undang-Undang Nomor 36 Tahun 2008.

Undang-Undang Nomor 8 Tahun 1983 tentang Pajak Pertambahan Nilai Barang dan Jasa dan Pajak Penjualan atas Barang Mewah yang telah diubah beberapa kali terakhir dengan Undang-Undang Nomor 42 Tahun 2009. 